\title{
Induction of Apoptosis of 2,4',6-Trihydroxybenzophenone in HT-29 Colon Carcinoma Cell Line
}

\author{
Ma Ma Lay, ${ }^{1}$ Saiful Anuar Karsani, ${ }^{1,2}$ and Sri Nurestri Abd Malek ${ }^{1}$ \\ ${ }^{1}$ Institute of Biological Sciences, Faculty of Science, University of Malaya, 50603 Kuala Lumpur, Malaysia \\ ${ }^{2}$ University of Malaya Centre for Proteomics Research (UMCPR), University of Malaya, 50603 Kuala Lumpur, Malaysia
}

Correspondence should be addressed to Ma Ma Lay; mamalayster@gmail.com

Received 24 August 2013; Accepted 22 October 2013; Published 22 January 2014

Academic Editor: Bruno C. Cavalcanti

Copyright (C) 2014 Ma Ma Lay et al. This is an open access article distributed under the Creative Commons Attribution License, which permits unrestricted use, distribution, and reproduction in any medium, provided the original work is properly cited.

2,4',6-Trihydroxy-4-methoxybenzophenone was isolated from the ethyl acetate fraction of Phaleria macrocarpa (Scheff.) Boerl. fruits. It was found to inhibit cell proliferation in HT-29 human colon carcinoma cell line but caused little damage to WRL-68 normal human liver and MRC-5 normal human fibroblast lung cell lines. The compound was found to sharply affect the viability of HT-29 cells in a dose- and time-dependent manner. HT-29 cells treated with the compound showed morphological changes under microscopic examination such as cell shrinkage, membrane blebbing, DNA fragmentation, and the occurrence of apoptotic nuclei. The percentage of early apoptotic, late apoptotic, and dead or necrotic cells was determined by flow cytometry using annexin V-FTIC/PI staining. In addition, flow cytometry showed that, when the HT-29 cells were treated with $115 \mu \mathrm{M}$ of the compound, it resulted in $G_{0} / G_{1}$ phase arrest in a time-dependent manner. Western blot revealed an upregulation of PUMA, Bak, Bcl-2, and Mcl-1 proteins suggesting that the compound induced apoptosis in HT-29 cells by regulating these proteins.

\section{Introduction}

Cancer refers to a family of diseases in which tissues multiply and spread unregulated throughout the body, the result of which may lead to death [1]. It is a major public health problem and has significantly increased the worldwide death rate. One of the most common types of cancer is colon cancer. Modern advances in cellular and molecular biology have increased our understanding of the various mechanisms of cancer [2]. Nowadays, there are many natural compounds and mechanism-based approaches to cancer treatment that have the potential to be successful. The development of anticancer drugs has also seen a massive contribution from natural products [2].

Phaleria macrocarpa (Scheff.) Boerl. is a medicinal plant belonging to the Thymelaeaceae family and in Indonesia it is locally known as Mahkota Dewa. The edible fruits of this plant are usually mixed with other Indonesian herbs and used in herbal medicine [3]. The fruits of P. macrocarpa consist of the skin which have a bright red color, a white, fibrous, and watery flesh, a shell, and a seed. In alternative medicine, it is used in the treatment of cancer, diabetes mellitus, nerve pain, kidney failure and disorder, liver dysfunction, serious illnesses, hypertension, skin diseases, and management of cholesterol levels.

Research on the use of the extracts of $P$. macrocarpa fruits as a possible anticancer agent is extensive. Prior research has shown that an ethanol extract from the flesh of the P. macrocarpa fruit toxic towards HeLa cell line derived from cervical carcinoma [4]. It has been shown that different parts of $P$. macrocarpa fruit showed excellent antioxidant activities and good anti-inflammatory and high cytotoxic activities against HT-29, MCF-7, and HeLa cell lines [5]. Gallic acid isolated from P. Macrocarpa has been shown to possess anticancer properties against human esophageal cancer cells (TE-2) but no cytotoxic effect was observed on noncancerous (CHEK1) cells [6]. The major compound of Phaleria obtained from P. macrocarpa fruits has been found to have high cytotoxic effect on MDA-MB231 breast cancer cell lines [7]. DLBS1425 of the extraction of $P$. macrocarpa flesh fruits inhibited proliferation of MDA-MB231 and MCF-7 cells, activation of caspase 9, and downregulation of Bax and Bcl-2 at the 


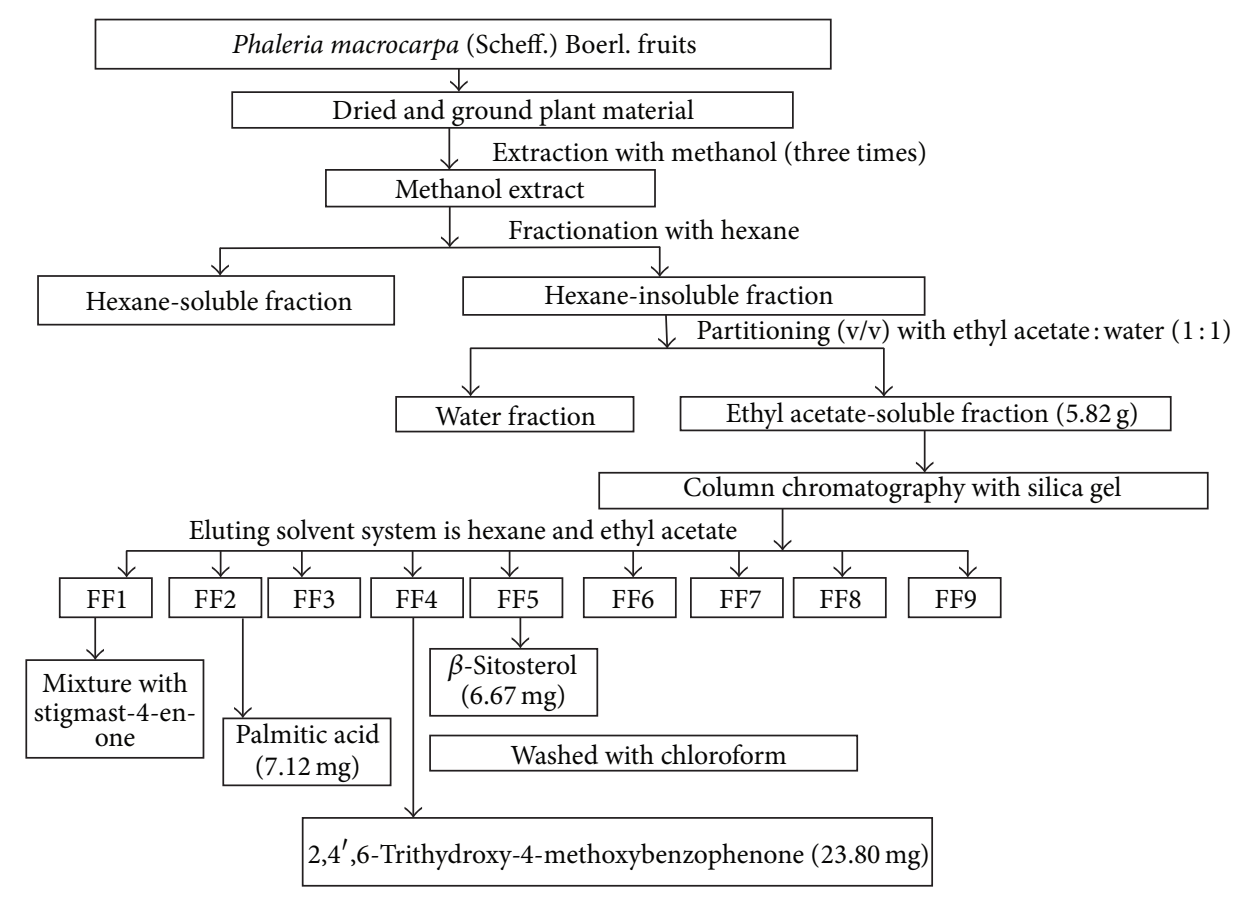

FIGURE 1: Extraction and isolation of bioactive compounds from ethyl acetate fraction of Phaleria macrocarpa (Scheff.) Boerl. fruits using silica gel column chromatography.

mRNA level [8]. In addition, it was also revealed that $2,6^{\prime}, 4-$ trihydroxy-4-methoxybenzophenone and 4',6-dihydroxy-4methoxybenzophenone 2-o- $\beta$-D-glucopyranoside isolated from the fruits displayed antiproliferation activity against the breast cancer cell line (MDA-MB231) and the formation of DNA fragments, as well as decreasing $\mathrm{Bcl} 2 \mathrm{mRNA}$ expression, increasing Bax mRNA expression and apoptosis inducer activity [9]. Furthermore, 2,6,4'-trihyroxy-4methoxybenzophenone from an ethyl acetate extract of the leaves of $P$. macrocarpa possessed good antioxidant activity [10].

In our present study, the bioactive $2,6^{\prime}, 4$-trihydroxy-4methoxybenzophenone was isolated from the ethyl acetate extract of the P. macrocarpa fruits and analyzed using gaschromatography mass spectrometry (GC-MS) and nuclear magnetic resonance, which were ${ }^{1} \mathrm{H},{ }^{13} \mathrm{C}$, DEPT, HMQC, and HMBC. The HT-29 human colon cancer cell line was then selected for evaluation of bioactivity and molecular mechanisms to examine the efficiency of 2,6 $6^{\prime}, 4$-trihydroxy4-methoxybenzophenone.

\section{Materials and Methods}

2.1. Extraction and Isolation of Bioactive Compounds. P. macrocarpa fruits were obtained from Yogyakarta, Indonesia (July 2009). The fruits (1 kg) were cut, washed, air-dried, and crushed. The powdered fruits were extracted with $70 \%$ methanol for three days at room temperature. The resulting solution was then filtered, combined, and concentrated under reduced pressure at $37^{\circ} \mathrm{C}$ using a rotary evaporator to yield a crude methanol extract. The methanol extract was then dissolved in hexane and this produced hexane soluble and insoluble fractions. The hexane soluble fraction was separated with water and an ethyl acetate solution $(1: 1)$ to yield water fractions and ethyl acetate fractions. The dried residue of the four extracts was then subjected to bioassays. The bioactive ethyl acetate fraction was subjected to column chromatography for isolation of bioactive compounds. The method for the extraction, fractions, and column chromatography of the fruits is summarized in Figure 1.

\subsection{Analysis of Bioactive Compounds}

2.2.1. Gas Chromatography-Mass Spectrophotometry (GC$M S)$. GC-MS was performed as previously described [11].

2.2.2. Nuclear Magnetic Resonance (NMR). The NMR analysis was carried out on a JEOL $400 \mathrm{MHz}$ FT-NMR, (JEOL, Japan) with TMS (tetramethylsilane) as the internal standard. Spectra were obtained from Proton ${ }^{1} \mathrm{H}-\mathrm{NMR}(400 \mathrm{MHz})$, carbon ${ }^{13} \mathrm{C}-\mathrm{NMR}(400 \mathrm{MHz}), \mathrm{HMBC}$, and HMQC analysis.

2.3. Preparation of Test Compound (2,4',6-Trihydroxy-4methoxybenzophenone). The test compound used was $2,4^{\prime}$, 6-trihydroxy-4-methoxybenzophenone isolated from P.macrocarpa. Stock solutions of 2,4',6-trihydroxy-4-methoxybenzophenone were prepared at a concentration of $38 \mathrm{mM}$ with absolute DMSO solution. The test sample was then prepared through serial dilution of the stock solution to give concentrations of $4 \mu \mathrm{M}, 38 \mu \mathrm{M}, 96 \mu \mathrm{M}, 192 \mu \mathrm{M}$, and $384 \mu \mathrm{M}$. The final concentration of DMSO in each treatment well was not in excess of $0.5 \%$ DMSO. 


\subsection{Cytotoxicity Screening for Bioactive Compounds}

2.4.1. Cell Culture. The HT-29 human colon carcinoma cell line, WRL-68 normal liver cells, and MRC-5 normal lung fibroblast carcinoma cells were purchased from the American Type Culture Collection (ATCC, USA). The cells were placed into tissue culture flasks and grown in a medium containing $10 \%$ fetal bovine serum, $100 \mu \mathrm{g} / \mathrm{mL}$ of penicillin/streptomycin, and $100 \mu \mathrm{g} / \mathrm{mL}$ of amphotericin B at $37^{\circ} \mathrm{C}$ in a humidified atmosphere containing $5 \% \mathrm{CO}_{2}$.

2.4.2. MTT Cell Proliferation Assay. The MTT (3,4,5-dimethylthiazol-2-yl)-2-5-diphenyltetrazolium bromide) cell proliferation assay was based on the protocol described by Mosmann [12]. Briefly, cells from a confluent tissue culture flask were spun at 1,000 rpm for five minutes and resuspended in $1.0 \mathrm{~mL}$ of growth medium. Cells were then seeded into 96 well plates and incubated in a $\mathrm{CO}_{2}$ incubator at $37^{\circ} \mathrm{C}$ for 24 hours to allow the cells to adhere and achieve $70 \%-80 \%$ confluence. After 24 hours, the media was removed and the test compound, at varying concentrations of $4,38,96,192$, and $384 \mu \mathrm{M}$ with $200 \mu \mathrm{L}$ of $10 \%$ medium, was added to the respective wells. For negative control, untreated cells were used. After $24 \mathrm{~h}, 48 \mathrm{~h}$, and $72 \mathrm{~h}$ of incubation, respectively, each well had $10 \mu \mathrm{L}$ of the MTT stock solution added to the test sample and was then incubated in a dark place for three hours. The medium with the MTT solution was removed and $200 \mu \mathrm{L}$ of absolute DMSO was added to each well in order to solubilise the formazan crystals that had formed. The total amount of formazan crystals was examined by measuring the absorbance at $540 \mathrm{~nm}$ using an ELISA plate reader. The assay was carried out in triplicate.

The percentage of inhibition (\%) was calculated using the following formula:

$$
\begin{aligned}
& \text { percentage of inhibition (\%) } \\
& =\frac{\text { OD control }- \text { OD sample } \times 100 \%}{\text { OD control }},
\end{aligned}
$$

where OD = optical densities.

The $\mathrm{IC}_{50}$ value is the concentration of test compounds which cause $50 \%$ inhibition or cell death, average from three experiments, and was obtained by plotting the percentage of inhibition versus the concentration of test compounds [13].

\subsection{Morphological Detection of Apoptosis}

2.5.1. Inverted and Phase-Contrast Microscopy. HT-29 cells were placed in a Petri dish $(30 \mathrm{~mm})$ at a density of $1 \times 10^{5}$ cells/well plate and grown for $24 \mathrm{~h}$. The test compound was then added at $\mathrm{IC}_{50}$ value and the cells were further incubated for $24 \mathrm{~h}, 48 \mathrm{~h}$, and $72 \mathrm{~h}$, respectively. After the various incubation periods, morphological changes in the apoptotic bodies of the HT-29 cells were examined by inverted and phasecontrast microscopy (Leica, Germany) and photographed.

2.5.2. Fluorescence Microscopy. HT-29 cells were placed in a Petri dish $(30 \mathrm{~mm})$ at a density of $1 \times 10^{5}$ cells/well plate and grown for $24 \mathrm{~h}$. The test compound (115 $\mu \mathrm{M})$ was added to each dish and the cells were further incubated for $72 \mathrm{~h}$. After the incubation period, the cells were detached with $0.25 \%$ accutase in phosphate buffer saline (PBS), the supernatant was discarded, and the cells were resuspended in $1 \mathrm{~mL}$ of PBS. Cells $(100 \mu \mathrm{L})$ were then incubated with $5 \mu \mathrm{L}$ of acridine orange (AO) and $5 \mu \mathrm{L}$ of propidium iodide (PI) for $10 \mathrm{~min}$ at room temperature in the dark. Stained cells $(10 \mu \mathrm{L})$ were put in three wells of the coated glass slides with $20 \mu \mathrm{L}$ of mounting media and stored at $-20^{\circ} \mathrm{C}$ prior to analysis. These double stained cells were photographed using a fluorescence microscope (Leica, Germany). All experiments were performed in triplicate.

2.6. Annexin V Staining Assay. The quantification of cell death was determined by flow cytometry using the Annexin V-FITC apoptosis detection kit according to the manufacturer's instructions (BD Pharmingen, BD Bioscience, USA). Briefly, $1 \times 10^{6}$ of the HT-29 cells were seeded into each Petri dish $(30 \mathrm{~mm})$ and after a $24 \mathrm{~h}$ incubation, various concentrations of the test compound were added and incubated for $24 \mathrm{~h}, 48 \mathrm{~h}$, and $72 \mathrm{~h}$, respectively. The cells were then washed with PBS, suspended in annexin $\mathrm{V}$ binding buffer and then added to an annexin V-FITC solution and propidium iodide (PI) for 10 minutes at room temperature. The samples were then analyzed using FACScalibur (BD Bioscience, USA) using CellQuest Pro analysis software (Becton Dickinson, USA).

2.7. Cell Cycle Analysis. HT-29 cells were placed in Petri dishes at a density of $1 \times 10^{5}$ cells/well and grown for $24 \mathrm{~h}$ and then the cells were treated with 2,4',6-trihydroxy-4methoxybenzophenone (at $\mathrm{IC}_{50}$ ) at $37^{\circ} \mathrm{C}$ for $24 \mathrm{~h}, 48 \mathrm{~h}$, and $72 \mathrm{~h}$. After incubation, the cells were collected by trypsinization, fixed in ethanol, washed in warm PBS, and incubated at $-20^{\circ} \mathrm{C}$, overnight. Next, the cells were washed with $1 \mathrm{~mL}$ of cold PBS and stained with propidium iodide according to the Cycle TEST PLUS DNA Reagent Kit (Becton Dickinson, USA) protocol. The cells were sorted in a FACScalibur flow cytometer (BD, USA) using CellQuest Pro software (Becton Dickinson, USA) and a quantitative analysis of the cell cycle distribution was performed using a trial version of the ModFit LT software, version 4.0.

2.8. Western Blot Analysis. The HT-29 cells were cultured in $25 \mathrm{~cm}^{3}$ tissue culture flasks and incubated at $37^{\circ} \mathrm{C}$ under $5 \% \mathrm{CO}_{2}$ until confluent. The cells were then treated with a double concentration of $\mathrm{IC}_{50}$ value for the 2,4',6-trihydroxy4-methoxybenzophenone for $24 \mathrm{~h}, 48 \mathrm{~h}$, and $72 \mathrm{~h}$, respectively. After incubation at the various times, the cells were detached with accutase in PBS, washed thoroughly with PBS twice, and were then lysed with protein lysis buffer (Sigma, USA) containingprotease inhibitors and shaken by hand for $15 \mathrm{~min}$ at room temperature. The lysates were then centrifuged at $13,000 \times \mathrm{g}$ for $20 \mathrm{~min}$ at $4^{\circ} \mathrm{C}$ and the supernatant was collected for protein samples and kept at $40^{\circ} \mathrm{C}$ until SDS page analysis. Protein concentration was determined using 
a BCA (bicinchoninic acid) protein assay kit (Invitrogen, USA) with bovine serum albumin as the standard.

The proteins were transferred into polyvinylidene difluoride (PVDF) membranes by semidry transfer. Bands were visualized using the Western Max Horseradish Peroxidase Chromogenic Detection Kit protocol (AMRESCO, USA). Briefly, the membranes were blocked in a blocking buffer for $30 \mathrm{~min}$ at room temperature. Primary antibodies for Bcl-2, Bcl-xL, PUMA, Mcl-1, Bak, Bad, and Bax were then added. The membranes were incubated with gentle agitation at room temperature overnight. After incubation, the membranes were washed with washing buffer two times and then incubated with Western Max HRP Conjugated Anti-Rabbit Antibody for $45 \mathrm{~min}$ at room temperature with gentle agitation. After discarding the secondary antibody solution, the membranes were washed twice and incubated with $\mathrm{DAB}$ substrate solution containing hydrogen peroxide at room temperature until a brown color developed. Finally, the membranes were dried, photographed, and stored in the dark.

2.9. Data Analysis. The numbers of viable cells were counted using a haemocytometer with trypan blue exclusion. MTT test was performed in triplicate. The data of the cytotoxicity assay was expressed as the mean \pm standard derivation (SD). The mean \pm standard derivations (SD) in each cell cycle phase were also calculated for the annexin V-FITC/PI double staining assay. The results from treated and untreated control cells were analyzed using Student's $t$-test. Differences with a $P$ value of $>0.05$ as determined using version 16.0 of SPSS were considered statistically significant.

\section{Results and Discussions}

3.1. Extraction and Isolation. The yield of dark brown methanol extract $(47.2 \mathrm{~g}, 4.7 \%)$, hexane fraction $(2.10 \mathrm{~g}$, $0.20 \%)$, ethyl acetate fraction $(12.2 \mathrm{~g}, 1.22 \%)$, and water fraction $(29.8 \mathrm{~g}, 2.90 \%)$ were determined. The ethyl acetate fraction (9.8 g) was subjected to silica gel column chromatography on a Merck Kieselgel 60 (400 g, 0.063-0.200 mm mesh size): initial elution with hexane, followed by ethyl acetate enriched with increasing percentages of acetone and monitored with TLC to give several main fractions: FF1 $(0.7 \mathrm{~g})$, FF2 (0.79 g), FF3 (0.42 g), FF4 (0.7 g), FF5 (0.5 g), FF6 (0.8), FF7 (1.5 g), FF8 (1.8 g), and FF9 (2.3 g). The components in these fractions were identified using GC-MS, NMR technique and some fractions were purified by recrystallization and separation with specific solvents.

GC-MS analysis of the ethyl acetate fraction of the $P$. macrocarpa showed the presence of phenol $(\mathrm{m} / \mathrm{z} 94), 2,6-$ dimethoxy phenol $(m / z 154)$, 2-methoxy phenol $(m / z 124), \beta$ sitosterol $(\mathrm{m} / z 414)$, stigmast-4-en-3-one $(\mathrm{m} / z$ 412), flamenol $(m / z 140)$, palmitic acid $(m / z 256)$, methyl palmitate, oleic acid $(m / z 264)$, and other unknown components.

A mixture with stigmast-4-en-3-one $(\mathrm{m} / z$ 276) was detected in (FF 1), $\beta$-Sitosterol $(\mathrm{m} / z$ 414) was obtained from fraction 5 (FF 5), and palmitic acid was also obtained from fraction 2 (FF2) by identification GC-MS analysis. The pure bioactive compound was obtained from fraction 4 (FF 4) after recrystallization. This compound was identified as $2,4^{\prime}, 6$ trihydroxy-4-methoxybenzophenone using NMR and GCMS analysis.

3.2. Identification of Isolated Bioactive Compound 2,4',6Trihydroxy-4-methoxybenzophenone or 2,6-Dihydroxy-4methoxyphenyl 4-Hydroxyphenyl methanone. The structure of this compound was established on the basis of EI-MS data together with ${ }^{1} \mathrm{H}$ and ${ }^{13} \mathrm{C}$ NMR spectra as shown in Figure 2(a). The peak at retention time $43.93 \mathrm{~min}$ in the total ion chromatogram of fraction $\mathrm{FF} 4$ gave a molecular ion peak at $m / z 260$ in the mass spectrum which was consistent with the molecular weight of 2,4',6-trihydroxy4-methoxybenzophenone having a molecular formula of $\mathrm{C}_{14} \mathrm{H}_{12} \mathrm{O}_{5}$. Fragment ions resulting from cleavages on either side of the carbonyl group were observed at $m / z=121$ and 93, respectively, as shown in Figure 3(a). The formation of other fragment ions is explained in Figure 2(b).

The two pairs of equivalent aromatic hydrogen, namely, $\mathrm{H}_{2^{\prime}} / \mathrm{H}_{6^{\prime}}$ and $\mathrm{H}_{3^{\prime}} / \mathrm{H}_{5^{\prime}}$ in ring $\mathrm{B}$ and a pair of equivalent aromatic hydrogens in ring $\mathrm{A}, \mathrm{H}_{3} / \mathrm{H}_{5}$, are visible at $\delta 7.59(\mathrm{~d})$, $6.75(\mathrm{~d})$, and 5.95 (s), respectively, in the ${ }^{1} \mathrm{H}$ NMR spectrum $\left(\mathrm{CDCl}_{3} / \mathrm{CD}_{3} \mathrm{OD}, 400 \mathrm{MHz}\right)$ (Table 1$)$. The corresponding three equivalent pairs of aromatic carbons, $\mathrm{C}_{2^{\prime}} / \mathrm{C}_{6^{\prime}}, \mathrm{C}_{3^{\prime}} / \mathrm{C}_{5^{\prime}}$, and $\mathrm{C}_{3} / \mathrm{C}_{5}$, can also be seen at $\delta 134.05,116.58$, and 95.35 in the ${ }^{13} \mathrm{C}$ NMR spectrum $\left(\mathrm{CDCl}_{3} / \mathrm{CD}_{3} \mathrm{OD}, 100 \mathrm{MHz}\right)$ in Figure 2(a). The signals also showed an aromatic methoxy group at $\delta 3.74$ and 55.86 in ${ }^{1} \mathrm{H}$ and ${ }^{13} \mathrm{C}$ NMR spectra, respectively. The ketone carbonyl signal appears at $\delta 199.59$. Along with the chemical shifts of the remaining carbons, the assignment of all the NMR signals is summarized in Table 1 and Figure 2(a). The assignment of ${ }^{1} \mathrm{H}$ and ${ }^{13} \mathrm{C}$ NMR signals is also summarized together with the ${ }^{1} \mathrm{H}_{-}{ }^{13} \mathrm{C}$ HMBC and HMQC data in Table 1 as well as in Figures 2(c) and 2(d).

\subsection{Cytotoxicity Screening Using MTT Cell Proliferation Assay}

3.3.1. Screening for Cytotoxic Activity of 2,4',6-Trihydroxy4-methoxybenzophenone. Cell proliferation is an important mechanism for the growth, development, and regeneration of eukaryotic organisms but it is, nevertheless, also the primary cause of some of the most debilitating diseases, one of which is cancer [14].

In this study, the cytotoxicity screening of the $2,4^{\prime}, 6$ trihydroxy-4-methoxybenzophenone against the HT-29 human colon carcinoma cell line was performed using the MTT cell proliferation assay and the cell viability of HT-29 cells was measured using the trypan blue exclusion assay. The HT-29 cells were treated with various concentrations (4, $38,96,192$, and $384 \mu \mathrm{M}$ ) for $24 \mathrm{~h}, 48 \mathrm{~h}$, and $72 \mathrm{~h}$, respectively. The results showed that inhibition of cell growth significantly increased in a dose-dependent and time-dependent manner when the HT-29 cells were treated with 2,4',6-trihydroxy-4methoxybenzophenone at $4,38,96,192$, and $384 \mu \mathrm{M}$ for $24 \mathrm{~h}$, $48 \mathrm{~h}$, and $72 \mathrm{~h}$ except for $96 \mu \mathrm{M}$ for $24 \mathrm{~h}$ as shown in Figures 3 (b) and 4(a). The $\mathrm{IC}_{50}$ values of the compound against the HT-29 cells were $172 \pm 2.21,144 \pm 2.66$, and $122 \pm 1.69 \mu \mathrm{M}$ 


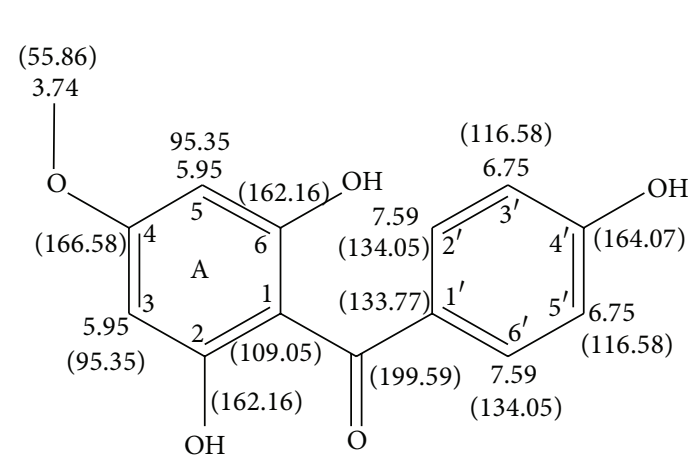

(a)

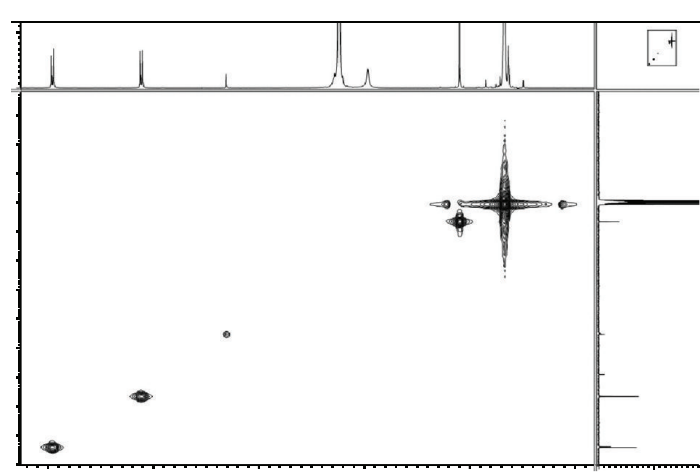

(c)

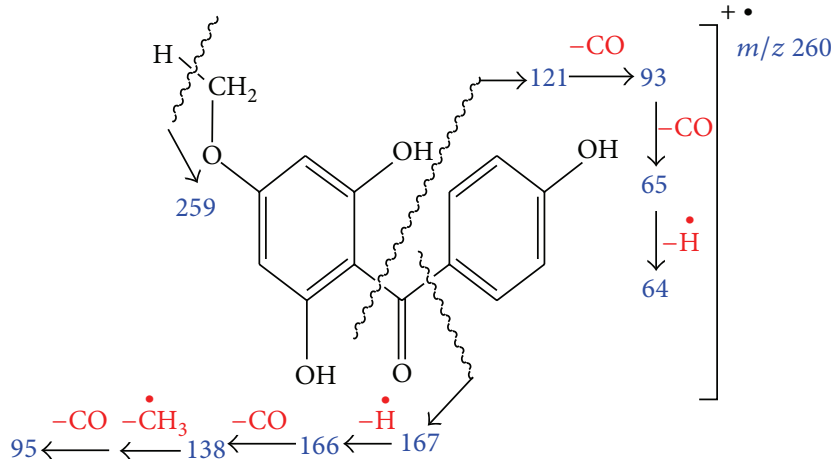

(b)

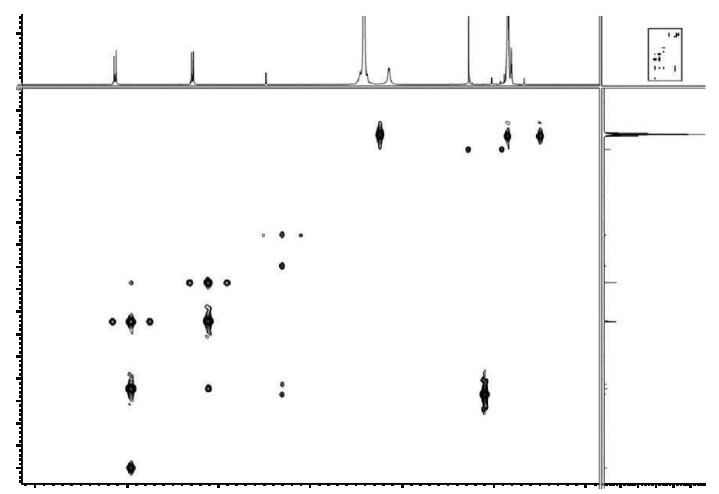

(d)

FIGURE 2: (a) Structure of 2,4',6-trihydroxy-4-methoxybenzophenone showing assignment of protons and carbons. (b) Proposed fragmentation of 2,4',6-trihydroxy-4-methoxybenzophenone. (c) HMBC analysis of isolated 2,4',6-trihydroxy-4-methoxybenzophenone. (d) HMQC analysis of isolated 2,4',6-trihydroxy-4-methoxybenzophenone.

for $24 \mathrm{~h}, 48 \mathrm{~h}$, and $72 \mathrm{~h}$. In contrast, the 2,4',6-trihydroxy-4methoxybenzophenone compound displayed mild cytotoxic effect on human normal liver cells (WRL-68) with $\mathrm{IC}_{50}$ values of $\geq 384 \pm 1.02,331 \pm 0.69$, and $235 \pm 1.03 \mu \mathrm{M}$ for $24 \mathrm{~h}, 48 \mathrm{~h}$, and $72 \mathrm{~h}$, respectively, as shown in Figure 3(d) and human normal fibroblast lung cells (MRC-5) with $\mathrm{IC}_{50}$ values of $\geq 384 \pm 1.00,269 \pm 0.96$, and $356 \pm 1.21 \mu \mathrm{M}$ for $24 \mathrm{~h}, 48 \mathrm{~h}$, and $72 \mathrm{~h}$, respectively, as shown in Figure 3(c).

3.4. Morphological Studies. HT-29 cells were treated with the isolated bioactive compound at $\mathrm{IC}_{50}$ concentrations $(115 \mu \mathrm{M})$ for incubation periods of $24 \mathrm{~h}, 48 \mathrm{~h}$, and $72 \mathrm{~h}$, respectively. After these incubation periods, the morphological changes in the cells were examined using inverted and phase-contrast microscopy. The cells displayed changes that are known to be associated to apoptosis including membrane blebbing, cell shrinkage, chromatin condensation, apoptotic nuclei, and DNA fragmentation, (Figures 4(a) and 4(b)).

3.5. Fluorescence Microscopy. The cells were observed under a fluorescence microscope at different excitations after staining with acridine orange and propidium iodide (AO/PI) for nuclei containing DNA. The results showed that the viable cells revealed the green nuclei, dead cells and late apoptotic and necrotic cells displayed red nuclei, and early apoptotic cells indicated orange nuclei in Figure 4(c). Thus, AO/PI staining of HT-29 showed that the cells had undergone remarkable morphological changes in apoptotic bodies.

3.6. Annexin V Staining Assay. The most important molecular mechanism used in the treatment of anticancer drugs is programmed cell death or apoptosis in the chemotherapeutic approach $[15,16]$. In our study, staining with Annexin VFITC and propidium iodide (PI) may distinguish between intact cells, early apoptosis, late apoptosis or cell death [17]. We also used single staining with Annexin V-FITC or PI to distinguish between live cells and dead cells; however, single staining could not distinguish between early apoptotic cells, late apoptotic cells or dead cells, or necrotic and live cells.

Cells were treated with various concentrations $(96 \mu \mathrm{M}$, $192 \mu \mathrm{M}$, and $288 \mu \mathrm{M}$ ) of the compound for $24 \mathrm{~h}, 48 \mathrm{~h}$, and $72 \mathrm{~h}$, respectively. They were then harvested with accutase and phosphate buffer saline and centrifuged, after which they were stained with Annexin V-FITC and propidium iodide and analyzed in FACScalibur with CellQuest Pro software. The number of early apoptotic cells, late apoptotic cells, live cells, and necrotic cells was counted in every 10,000 cells of each treatment [18]. All data was expressed as the mean \pm SD (standard deviation). The standard deviation was calculated for the treated and untreated cells. The SPSS program (version 

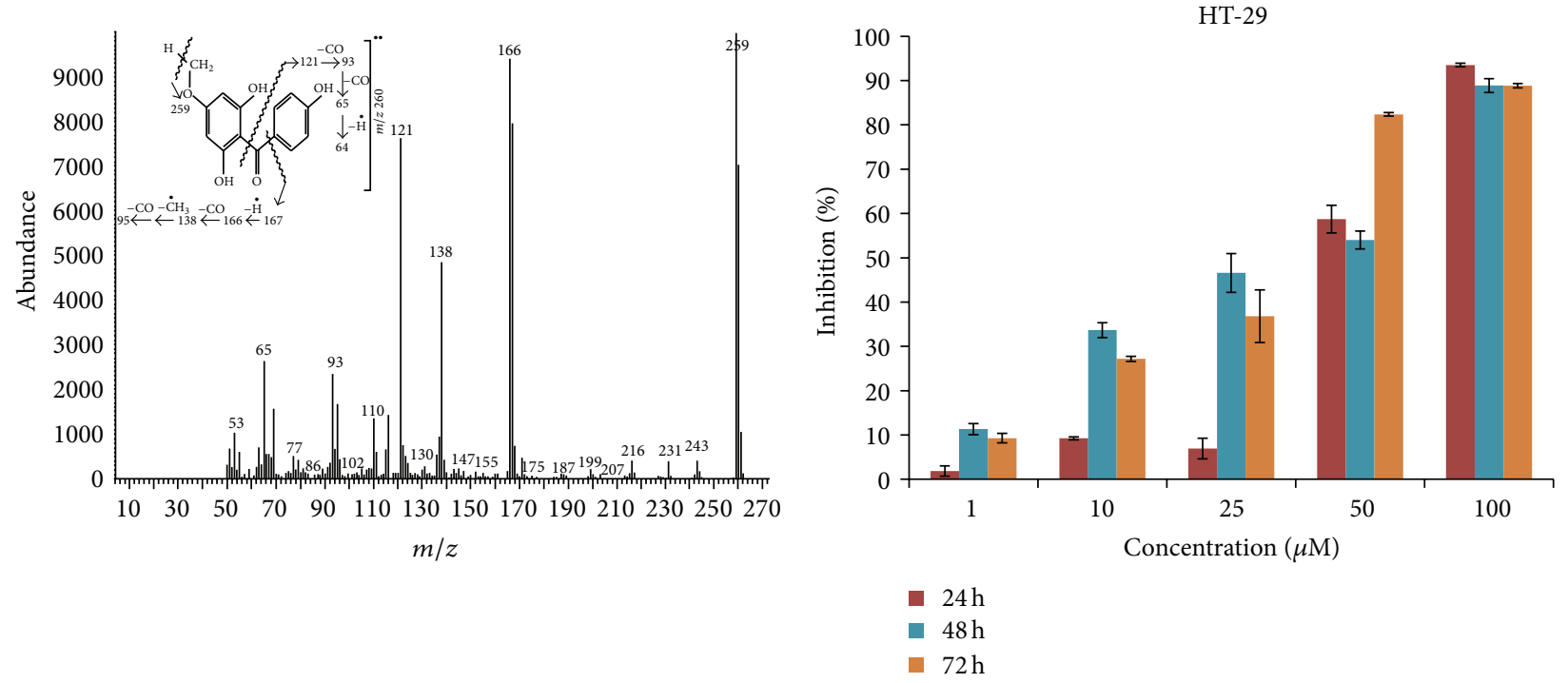

(a)
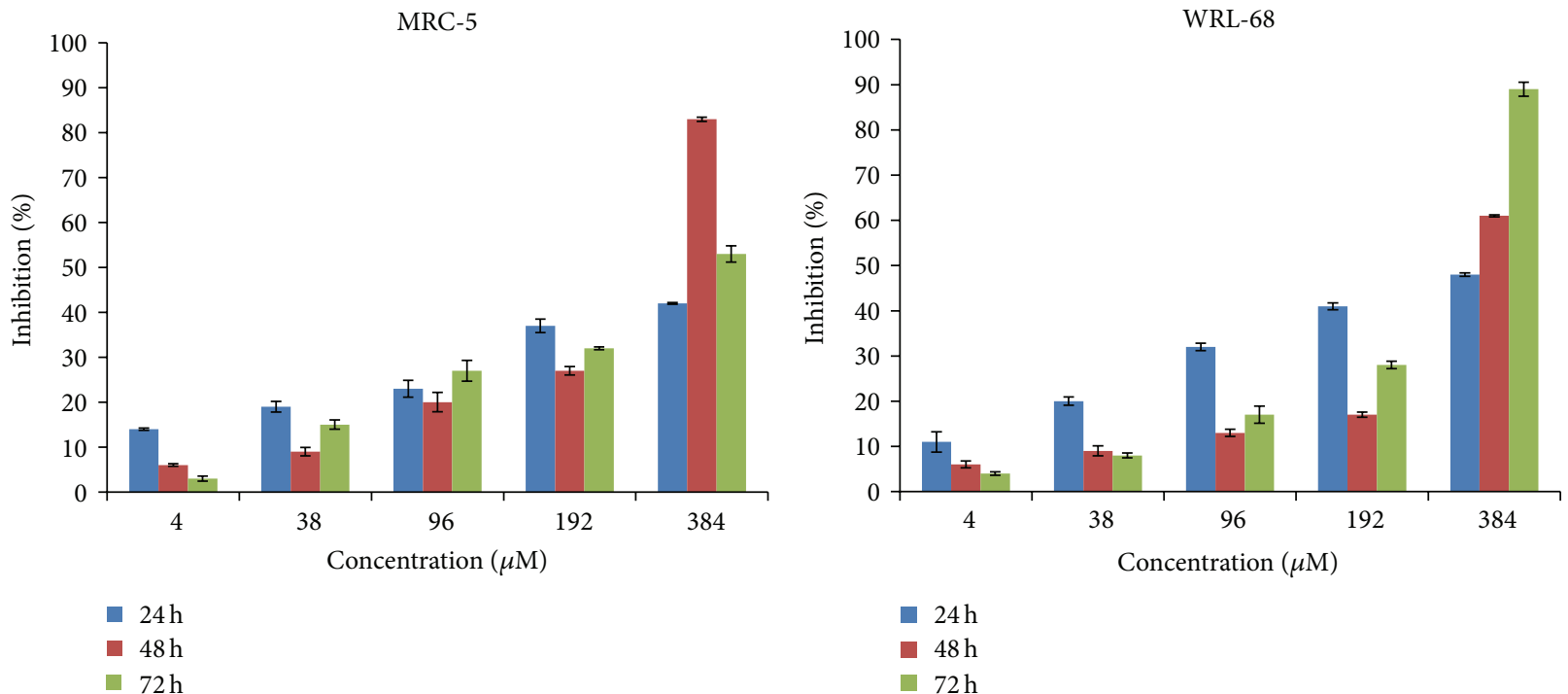

(c)

(d)

Figure 3: (a) Mass-spectrum of gas chromatography mass spectrometry (GC-MS) analysis of 2,4',6-trihydroxy-4-methoxybenzophenone, (b) In vitro, cytotoxic effects of 2,4',6-trihydroxy-4-methoxybenzophenone on (b) HT-29 colon cancer cells, (c) MRC-5 normal lung cells and (d) WRL-68 normal fibroblast cells. Cells were treated with various concentrations of 2,4,6'-trihydroxy-4-methoxybenzophenone from ethyl acetate fraction of Phaleria macrocarpa (Scheff.) Boerl. fruits for $24 \mathrm{~h}, 48 \mathrm{~h}$, and $72 \mathrm{~h}$ prior to the determination of cytotoxicity by MTT cell proliferation assay. Each value is expressed as mean \pm standard deviation of three measurements.

16.0) found a significant difference between the treated and untreated cells $(P>0.05)$.

In flow cytometry analysis of Annexin V-FITC/PI double staining, the late or secondary necrotic apoptotic cells were visible in the upper right (UR) and early apoptotic cells in the lower right (LR) quadrants, while the primary necrotic cells were visible in the upper left (UL) and live cells in the lower left (LL) quadrants, respectively. In untreated HT29 cells, $92.28 \%$ of the cells were viable, $1.85 \%$ was in early apoptosis and $3.21 \%$ cells were in late apoptosis, or secondary necrotic stage. When the HT-29 cells were treated with
$96 \mu \mathrm{M}, 192 \mu \mathrm{M}$, and $288 \mu \mathrm{M}$ of the compound for $24 \mathrm{~h}$, the viable cells were $69.26 \%, 35.16 \%$, and $23.83 \%$, the primary necrotic cells were $15.49 \%, 30.40 \%$, and $19.63 \%$, the early apoptotic cells were $2.96 \%, 8.46 \%$, and $6.71 \%$, and the late apoptotic cells were $12.28 \%, 25.98 \%$, and $50.81 \%$, respectively. After $48 \mathrm{~h}$ incubation, live cells were at $49.61 \%, 34.22 \%$, and $26.80 \%$, primary necrotic cells were at $8.04 \%, 35.05 \%$, and $10.02 \%$, early apoptotic cells were at $10.87 \%, 4.74 \%$, and $8.51 \%$, and late apoptotic cells were at $31.48 \%, 25.55 \%$, and $54.67 \%$, respectively. After $72 \mathrm{~h}$ incubation, live cells were at $52.21 \%$, $12.73 \%$, and $54.64 \%$, primary necrotic cells were at $30.69 \%$, 
TABLE 1: ${ }^{1} \mathrm{H}$ NMR $\left(\mathrm{CDCl}_{3} / \mathrm{CD}_{3} \mathrm{OD}, 400 \mathrm{MHz}\right),{ }^{13} \mathrm{C} \mathrm{NMR}\left(\mathrm{CDCl}_{3} / \mathrm{CD}_{3} \mathrm{OD}, 100 \mathrm{MHz}\right), \mathrm{HMQC}$, and HMBC data of isolated 2,4 $4^{\prime}$,6-trihydroxy4-methoxybenzophenone or 2,6-dihydroxy-4-methoxyphenyl 4-hydroxyphenyl methanone.

\begin{tabular}{lcccc}
\hline Position/group & $\delta \mathrm{C}$ & $\delta \mathrm{H}(\mathrm{mult}, \mathrm{J}$ in $\mathrm{Hz})$ & ${ }^{1} \mathrm{H}-{ }^{13} \mathrm{C}$ HMBC & - \\
\hline 1 & 109.05 & - & - & - \\
$2 / 6$ & 162.16 & - & $\mathrm{HMQC}$ \\
$3 / 5$ & 95.35 & $5.95(s)$ & - & - \\
4 & 166.58 & - & - & - \\
$1^{\prime}$ & 133.77 & - & $\mathrm{C}-3 / \mathrm{C}-5$ \\
$2^{\prime} / 6^{\prime}$ & 134.05 & $7.59(d, 8.8)$ & - \\
$3^{\prime} / 5^{\prime}$ & 116.58 & $6.75(d, 8.8)$ & $\mathrm{C}-1^{\prime}, \mathrm{C}-3^{\prime} / \mathrm{C}-5^{\prime}, \mathrm{C}-4^{\prime}, \mathrm{C}=\mathrm{O}, \mathrm{C}-2^{\prime} / \mathrm{C}-6^{\prime}, \mathrm{C}-4^{\prime}$ & - \\
$4^{\prime}$ & 164.07 & - & - & $\mathrm{C}-2^{\prime} / \mathrm{C}-6^{\prime}$ \\
$\mathrm{C}=\mathrm{O}$ & 199.59 & - & - & - \\
$\mathrm{OCH}_{3}$ & 55.86 & $3.74(s)$ & $\mathrm{C}-4$ & $\mathrm{COCH}_{3}^{\prime}$ \\
\hline
\end{tabular}
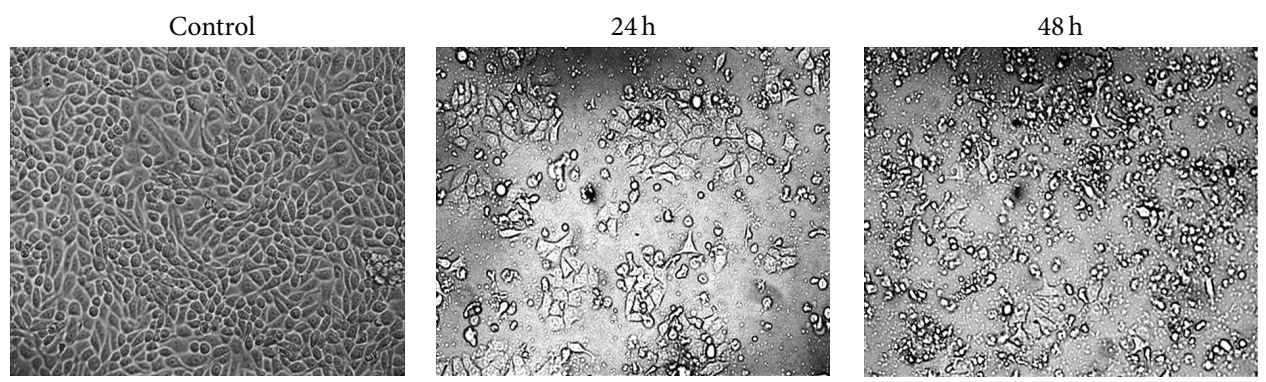

(a)
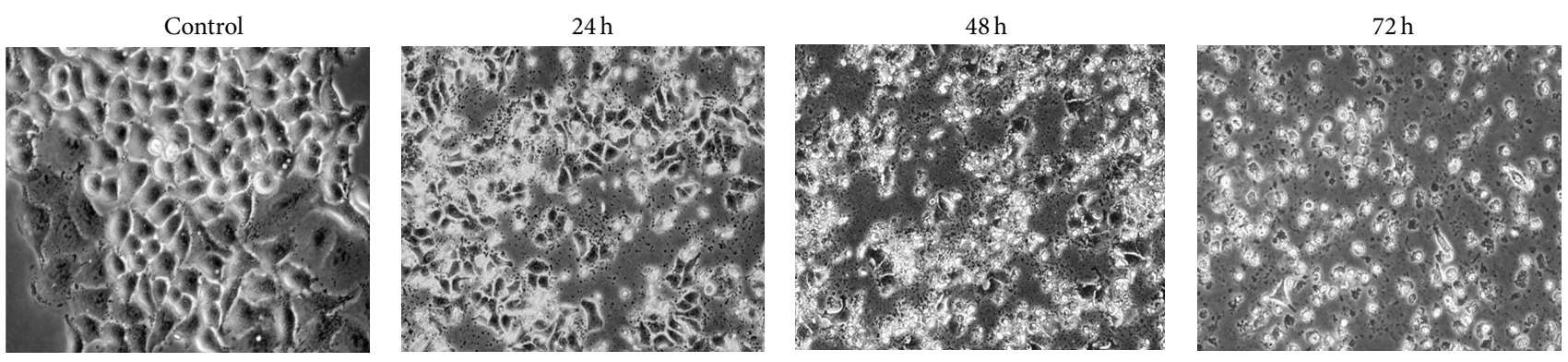

(b)
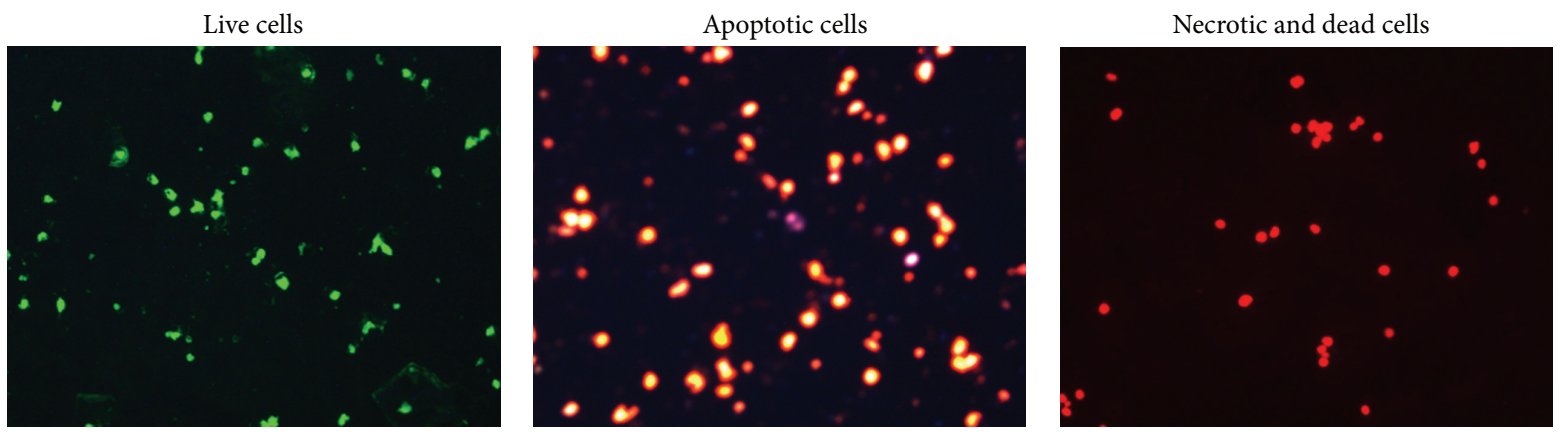

(c)

Figure 4: (a) Cells were treated with compound $(30 \mu \mathrm{M})$ for $24 \mathrm{~h}, 48 \mathrm{~h}$, and $72 \mathrm{~h}$ which induced morphological changes typical of apoptosis in HT-29 colon carcinoma cells. Control or treated cells were observed under inverted microscope and photographed. (b) Control or treated cells were observed under phase contrast microscope and photographed. (c) Treatment with $\mathrm{IC}_{50}$ value $(30 \mu \mathrm{M})$ of $2,4^{\prime}, 6$-trihydroxy-4methoxybenzophenone for $48 \mathrm{~h}$ induces morphological changes typical of apoptosis in HT-29 colon cancer cells. After being stained with acridine orange and propidium iodide, treated cells were observed under fluorescence microscopy-live cells stained (green colour), apoptotic cells (orange), and necrotic cells or dead cells (red). 
$13.96 \%$ and $36.63 \%$, early apoptotic cells were at $1.33 \%, 14.34 \%$ and $0.28 \%$, and late apoptotic or secondary necrotic cells were at $15.77 \%, 58.97 \%$, and $8.45 \%$, respectively. All these data are shown in Figures 5(a) and 5(b).

The results indicated that the effects of programmed cell death or apoptosis on HT-29 colon carcinoma cells were induced by $2,4^{\prime}, 6$-trihydroxy-4-methoxybenzophenone in a time-and dose-dependent manner.

3.7. Cell Cycle Analysis. One of the most important mechanisms in anticancer drug treatment is cell cycle arrest, which can be measured by DNA content. DNA (deoxyribonucleic acid) plays an essential role in cell reproduction and cell life and death and also carries genetic information for all living organisms and consists of two sets of chromosomes $[15,16]$. When $2 \mathrm{~N}$ DNA is present in the $\mathrm{G}_{0}$ and $\mathrm{G}_{1}$ phases of each cell cycle, the $G_{2}$ and $M$ phases in the cell cycle are presented by $4 \mathrm{~N}$ DNA which has a double $2 \mathrm{~N}$ number of chromosomes while the S-phase synthesizes DNA replication using flow cytometry analysis.

The HT-29 cells were treated with isolated bioactive 2,4',6-trihydroxy-4-methoxybenzophenone for $24 \mathrm{~h}, 48 \mathrm{~h}$, and $72 \mathrm{~h}$. Treated and untreated cells were harvested with accutase and phosphate buffer saline, centrifuged, and stained with propidium iodide. The HT-29 cells were then analyzed by flow cytometry using CellQuest Pro software and their distribution in different phases of the cell cycle is shown in Figure 6(a). The resulting data were tabulated using the trial version of the ModFit L.V 4.0 software to represent a percentage of each cell cycle phase $\left(G_{0} / G_{1}, S\right.$, and $\left.G_{2} / M\right)$, as shown in Figure 6(b).

Treatment with the 2,4',6-trihydroxy-4-methoxybenzophenone compound (at $\mathrm{IC}_{50}$ value of $115 \mu \mathrm{M}$ ) resulted in cell cycle arrest in the $G_{0} / G_{1}$ phase in a time-dependent manner. Standard deviation was calculated for the treated and untreated cells. The significance of the difference between the treated and untreated cells in each cell cycle phase, namely, $\mathrm{G}_{0} / \mathrm{G}_{1}, \mathrm{~S}$ and $\mathrm{G}_{2} / \mathrm{M}$, was determined by Student's $t$-test and the $P$ value was $>0.05$ using SPSS, version 16.0.

After incubation for $24 \mathrm{~h}, 48 \mathrm{~h}$, and $72 \mathrm{~h}$, the percentage of diploid cells in the $G_{0} / G_{1}$ phase progressively increased to $70.69 \%, 79.98 \%$, and $88.21 \%$ and the cell percentage in the $\mathrm{G}_{2} / \mathrm{M}$ and $\mathrm{S}$ phases was $13.61 \%, 3.17 \%$, and $3.20 \%$ and $15.70 \%, 16.85 \%$, and $8.60 \%$, respectively (Figure $6(\mathrm{~b})$ ). The aneuploid cells in the $G_{0} / G_{1}$ and $S$ phases were not stable because of abnormal chromosome problems in the centrioles where extra or missing chromosomes occurred.

Every diploid cell has two sets of chromosomes $(2 \mathrm{~N})$ which occur in the $G_{0} / G_{1}$ phase of each cell cycle and tetraploid cells have double the normal $2 \mathrm{~N}$ number of chromosomes $(4 \mathrm{~N})$, which occur in the $\mathrm{G}_{2} / \mathrm{M}$ phase of each cell cycle; however, aneuploidy refers to an abnormal number of chromosomes, which was observed as a significant difference between the $G_{0} / G_{1}$ and $G_{2} / M$ phases in the flow cytometry analysis. We observed that the number of diploid cells and tetraploid cells in the $G_{0} / G_{1}$ and $S$ phases of each cell cycle were heavily reliant on one another.
Thus, we have shown here that 2,4',6-trihydroxy-4methoxybenzophenone at $115 \mu \mathrm{M}$ induced apoptosis in HT29 cells during $\mathrm{G}_{0} / \mathrm{G}_{1}$ arrest and the inhibition of cell growth could be a result of the induction of apoptosis, which may be resolved by cell cycle arrest, which may consequently result in programmed cell death.

3.8. Western Blot Analysis. Apoptosis or programmed cell death consists of three major pathways: the intrinsic pathway, the extrinsic or death-receptor pathway, and the signalling pathways that indicates death-associated proteolytic or nucleolytic activities.

The Bcl-2 family of proteins play an essential role in regulating the mitochondria-dependent pathway of apoptosis for health and diseases [19]. Bcl-2 proteins are alternative targets for both pro- and antiapoptotic therapeutic approaches [20]. There are two groups of proteins involved in apoptosisantiapoptotic or prosurvival proteins, such as $\mathrm{Bcl}-2, \mathrm{Bcl}-\mathrm{xl}$ Bcl-w, Mcl-1, and A1 and proapoptotic proteins such as Bax, Bak, PUMA, Bok, Bad, Bid, Bik, Blk, Hrk, BNIP3, and BimL. The Bcl-2 family of proteins have been shown to regulate apoptosis in response to chemotherapy, both in vivo and in vitro $[21,22]$. The Bcl-2 family of proteins are located in the endoplasmic reticulum membrane, the nuclear envelope, and in the mitochondrion's outer membranes [23]. The Bcl-2 prosurvival proteins directly or indirectly regulate the release of cytochrome $\mathrm{c}$ from mitochondria.

A member of the $\mathrm{BH} 3$ subgroup of the Bcl-2 family of proteins is PUMA (p53-upregulated mediator of apoptosis), which interacts with antiapoptotic Bcl-2 family proteins such as $\mathrm{Bcl}-\mathrm{xL}, \mathrm{Bcl}-2, \mathrm{Mcl}-1, \mathrm{Bcl}-\mathrm{w}$, and $\mathrm{Al}$ or proapoptotic proteins such as Bax and Bak. It also involves p53-dependent and p53-independent apoptosis induced by different signalling pathways. Another antiapoptotic protein from the $\mathrm{Bcl}-2$ family is the myeloid cell leukemia sequence 1 ( $\mathrm{Mcl}$ 1), which is involved in the upregulation of apoptosis and survival regulation, and also plays a part in melanoma cell resistance towards Fas-mediated apoptosis. Inhibiting the mitochondrial signalling pathway of apoptosis can directly affect cancer therapy. It is well known that Bcl-2 is a potent antiapoptotic protein which is expressed in HT-29 cells. In our study, the expression of apoptosis and cell cycle associated proteins was determined using western blotting after the HT-29 cells were treated with 2,4',6-trihydroxy4-methoxybenzophenone. The expression of antiapoptotic (Bcl-2 and $\mathrm{Mcl}-1$ ) and proapoptotic protein (PUMA and Bak) in HT-29 colon human adenocarcinoma cells line was examined using the western blot technique. To clarify the mechanisms by which the compound induced apoptosis of HT-29 cells, the cells were incubated at an $\mathrm{IC}_{50}$ concentration $(115 \mu \mathrm{M})$ of $4^{\prime}, 6$-trihydroxy-4-methoxybenzophenone for $24 \mathrm{~h}, 48 \mathrm{~h}$, and $72 \mathrm{~h}$. Proteins were then extracted for western blotting. As is shown in Figures 6(c) and 6(d), the expression of Mcl-1 and PUMA was significantly upregulated when the HT-29 cells were treated with the compound for $24 \mathrm{~h}, 48 \mathrm{~h}$ and $72 \mathrm{~h}$. The expression of Bcl-2 and Bak was only 


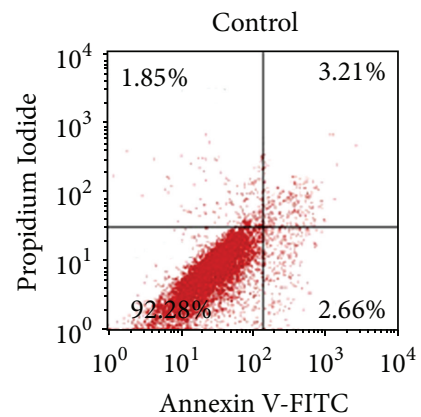

$24 \mathrm{~h}$
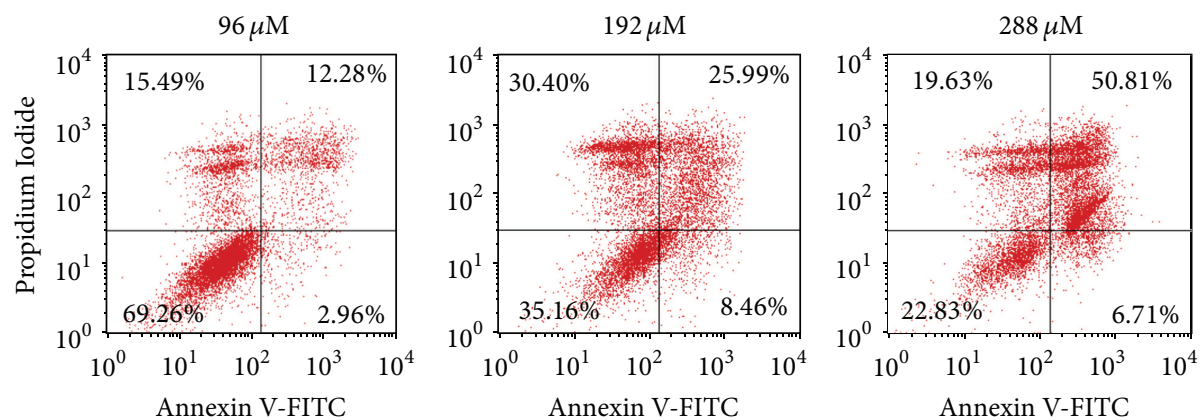

$48 \mathrm{~h}$
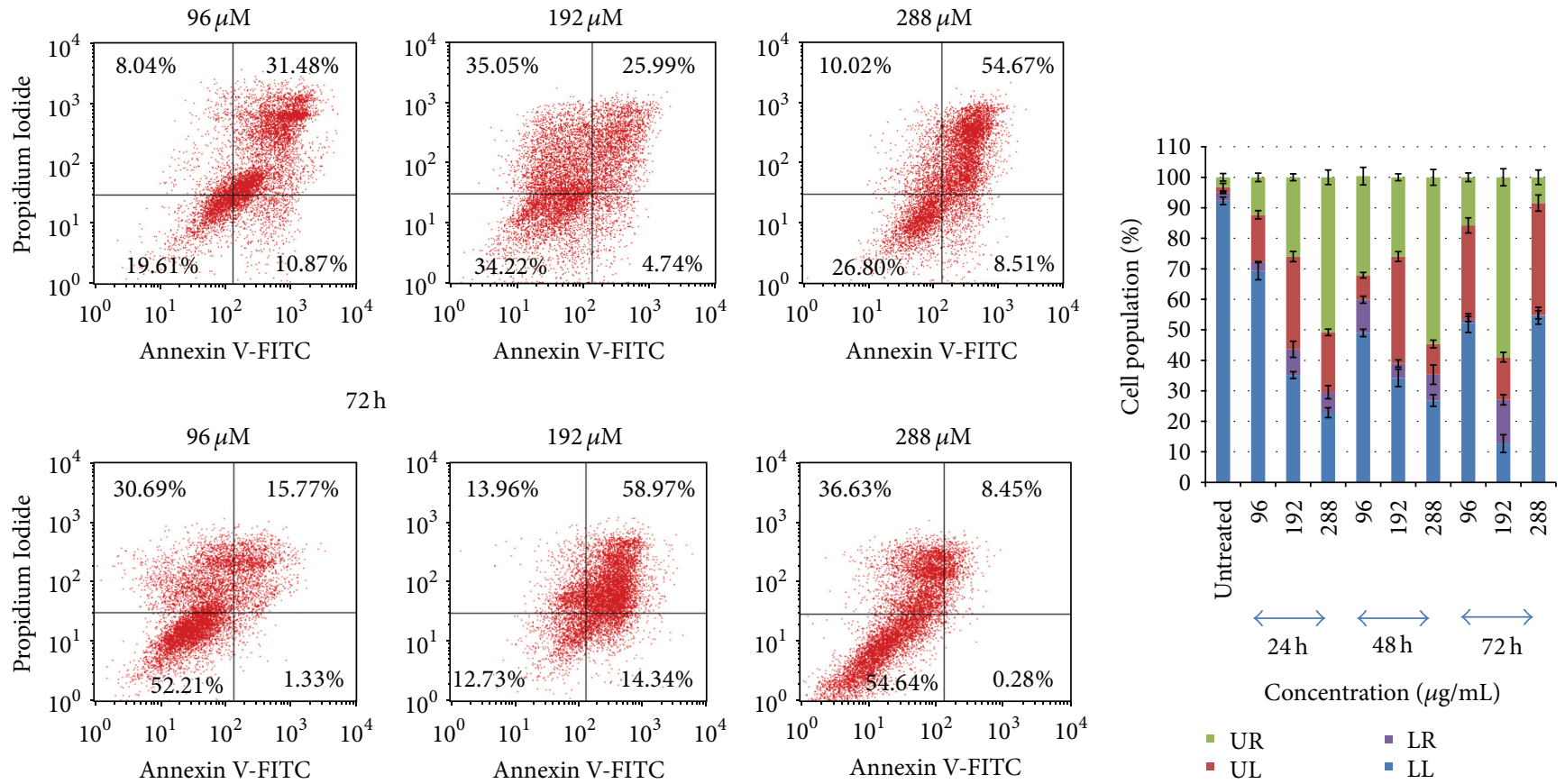

(a)

(b)

Figure 5: (a) Effects of 2,4',6-trihydroxy-4-methoxybenzophenone on induction of apoptosis in HT-29 cells. The cells were treated with different concentrations of compound $(25 \mu \mathrm{M}, 50 \mu \mathrm{M}$, and $75 \mu \mathrm{M})$ in a time-dependent manner $(24 \mathrm{~h}, 48 \mathrm{~h}$, and $72 \mathrm{~h})$, labelled with FITC annexin V and PI. Viable cells = LL; Early apoptotic cells = LR; late or secondary necrotic cells = UR; primary necrotic cells = UL. (b) Histogram representation of the quantitative percentage of viable cells (LL), early apoptotic cells (LR), primary necrotic cells (UL), and late apoptotic cells or secondary necrotic cells (UR) of HT-29 treatment with different concentration of 2,4',6-trihydroxy-4-methoxybenzophenone for $24 \mathrm{~h}, 48 \mathrm{~h}$, and $72 \mathrm{~h}$. 

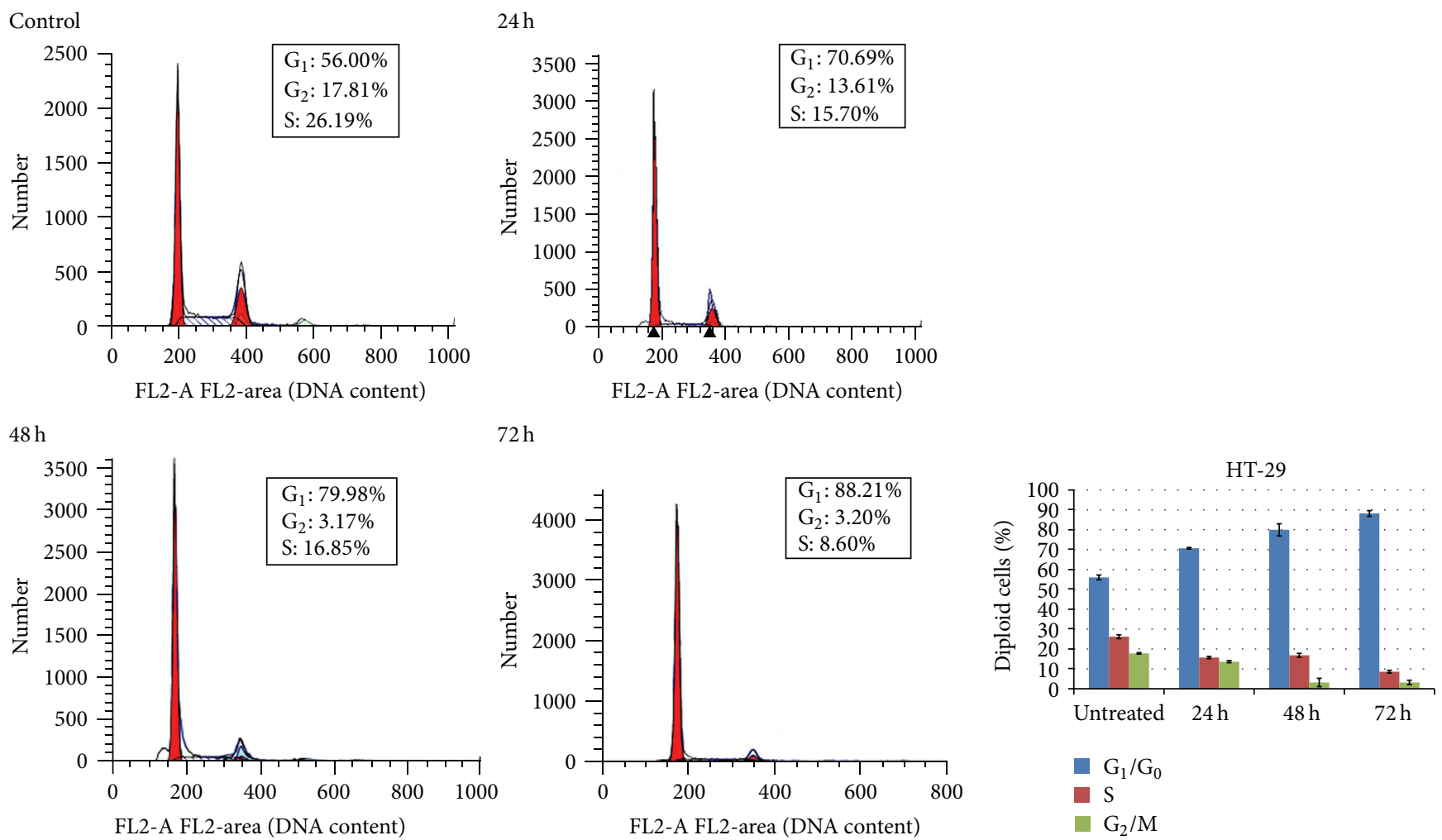

(a)

(b)

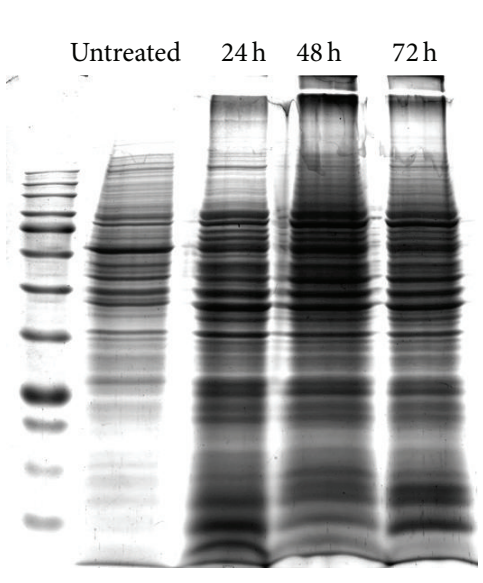

(c)

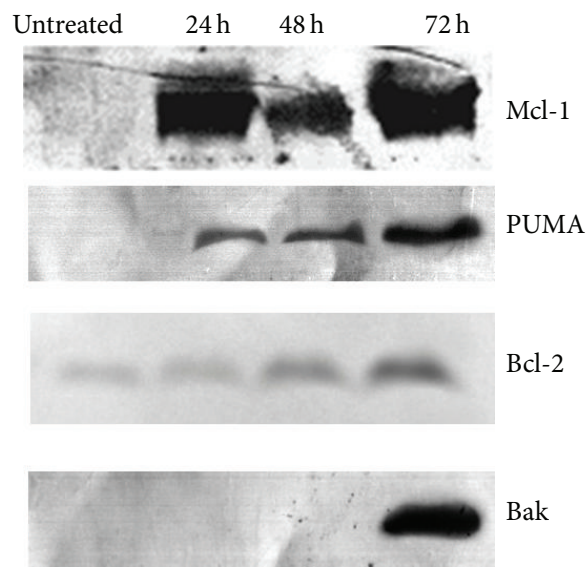

(d)

Figure 6: (a) Effect of 2,4',6-trihydroxy-4-methoxybenzophenone on HT-29 cell cycle. Cells were treated with the $\mathrm{IC}_{50}$ value $(30 \mu \mathrm{M})$ concentrations of compound for $24 \mathrm{~h}, 48 \mathrm{~h}$, and $72 \mathrm{~h}$ and analyzed by flow cytometry after staining with PI. Percentages of diploid cells (DNA content) at $G_{0} / G_{1}, S$, and $G_{2} / M$ phases of HT-29 cells were determined after $24 \mathrm{~h}, 48 \mathrm{~h}$, and $72 \mathrm{~h}$ incubation periods. (b) Histogram showing quantitative percentage of diploid cells (DNA content) in each cell cycle phase without treatment and with treatment. (c) The expression of the whole protein in Coomassie blue staining after compound induced apoptosis in HT-29 cells. (d) The expression of antiapoptotic protein and proapoptotic protein in western blotting analysis.

up-regulated for $72 \mathrm{~h}$ treatment of HT-29 cells. In apoptosisrelated protein expression after treatment with the compound in HT-29 cells, the upregulation of Bcl-2 was found to be in a time-dependent manner. Our results showed that the $\mathrm{G}_{0} / \mathrm{G}_{1}$ arrest and apoptosis of the 2,4',6-trihydroxy-4methoxybenzophenone in HT-29 cells might be associated with the upregulation of the anti-apopptotic proteins $\mathrm{Bcl}$ 2 and Mcl-1, as well as the pro-apototic proteins Bak and
PUMA. Recent researchers also demonstrated that DLBS1425 showed downregulation of Bax and Bcl-2 which are COX2, cPLA2, and VEGF-C and c-fos and HER-2/neu mRNA expression in MDA-MB231 cells [8]. Using western blotting, we showed that $\mathrm{Bcl}-2, \mathrm{Mcl}-1$, and Bak and PUMA regulation may be involved in compound-induced apoptosis. Thus, we have shown that the Bcl-2 family of proteins may be directly or indirectly involved in the apoptotic effect of the compound 
in HT-29 colon human carcinoma cell lines and that the 2,4',6-trihydroxy-4-methoxybenzophenone may induce apoptosis in HT-29 cells through pathways involving Bcl-2.

\section{Conclusion}

Our study showed that 2,4',6-trihydroxy-4-methoxybenzophenone inhibits cell proliferation and is able to induce apoptosis in HT-29 cells. Western blot analysis suggested that the compound induced apoptosis by upregulating Bcl2, PUMA, Mcl-1, and Bak proteins. These data suggested that the mechanism of cell cycle arrest in the $G_{0} / G_{1}$ phase may be related to $\mathrm{Bcl}-2$ proteins and play a vital role in regulating the mitochondria-dependent pathway of apoptosis.

\section{Abbreviations}

$\begin{array}{ll}\text { g: } & \text { Gram } \\ \text { mL: } & \text { Milliliter } \\ \text { min: } & \text { Minutes } \\ \text { h: } & \text { Hours } \\ \text { m/z: } & \text { Molecular weight }\end{array}$

AO/PI: Acridine orange and propidium iodide.

\section{Conflict of Interests}

The authors declare that there is no conflict of interests regarding the publication of this paper.

\section{Acknowledgments}

This project was supported by grants from the Ministry of Higher Education (nos. PS286/2009C and PS470/2010B). The authors would like to acknowledge the laboratory staff of the Institute of Medical Research (IMR, Malaysia) for their valuable technical assistance in the flow cytometry analysis. The authors are also thankful to Professor Dr. Amru Bin Nasrulhaq Boyce for allowing them to use his laboratory. Special thanks are also due to the Merit Islamic Development Bank scholarship (IDB, Saudi Arabia) for financial support for Ma Ma Lay.

\section{References}

[1] L. J. Kleinsmith, Principles of Cancer Biology, Pearson/Benjamin Cummings, 2003.

[2] G. M. Cooper, The Cancer Book, Jones and Barlett, Boston, Mass, USA, 1993.

[3] D. Kurnia, K. Akiyama, and H. Hayashi, "29-norcucurbitacin derivatives isolated from the Indonesian medicinal plant, $P h a-$ leria macrocarpa (Scheff.) Boerl," Bioscience, Biotechnology and Biochemistry, vol. 72, no. 2, pp. 618-620, 2008.

[4] E. Susanthy, "N-hexane extract cytotoxicity Beans andMeat Mahkota Dewa Fruit (Phaleria macrocarpa [Scheff.] Boerl.) Against HeLa and Myeloma Cell Line," pp. 47-50, 2005.

[5] R. Hendra, S. Ahmad, E. Oskoueian, A. Sukari, and M. Y. Shukor, "Antioxidant, Anti-inflammatory and cytotoxicity of Phaleria macrocarpa (Boerl.) Scheff Fruit," BMC Complementary and Alternative Medicine, vol. 11, article 110, 2011.
[6] A. Faried, D. Kurnia, L. S. Faried et al., "Anticancer effects of gallic acid isolated from Indonesian herbal medicine, Phaleria macrocarpa (Scheff.) Boerl, on human cancer cell lines," International Journal of Oncology, vol. 30, no. 3, pp. 605-613, 2007.

[7] O. M. Tandrasasmita, J. S. Lee, S. H. Baek, and R. R. Tjandrawinata, "Induction of cellular apoptosis in human breast cancer by DLBS1425, a Phaleria macrocarpa compound extract, via downregulation of PI3-kinase/AKT pathway," Cancer Biology \& Therapy, vol. 10, no. 8, pp. 814-824, 2010.

[8] R. R. Tjandrawinata, P. F. Arifin, O. M. Tandrasasmita, D. Rahmi, and A. Aripin, "DLBS1425, a Phaleria macrocarpa (Scheff.) Boerl. extract confers anti proliferative and proapoptosis effects via eicosanoid pathway," Journal of Experimental Therapeutics and Oncology, vol. 8, no. 3, pp. 187-201, 2010.

[9] A. Aripin, P. F. Arifin, and R. R. Thandrawinata, "Isolated compounds from Phaleria macrocarpa as anti-cancer agents," US Patent Application No: 2011/0257,112, 2011.

[10] Susilawati, S. Matsjeh, H. D. Pranowo, and C. Anwar, "Antioxidant activity of 2,6,4'-trihyroxy-4-methoxy benzophenone from ethyl acetate extract of leaves of Mahkota Dewa (Phaleria macrocarpa (Scheff.) Boerl," Indonesian Journal of Chemistry, vol. 11, no. 2, pp. 180-185, 2011.

[11] S. N. A. Malek, C. W. Phang, H. Ibrahim, N. A. Wahab, and K. S. Sim, "Phytochemical and cytotoxic investigations of Alpinia mutica rhizomes," Molecules, vol. 16, no. 1, pp. 583-589, 2011.

[12] T. Mosmann, "Rapid colorimetric assay for cellular growth and survival: application to proliferation and cytotoxicity assays," Journal of Immunological Methods, vol. 65, no. 1-2, pp. 55-63, 1983.

[13] S. N. A. Malek, S. K. Shin, N. A. Wahab, and H. Yaacob, "Cytotoxic components of Pereskia bleo (Kunth) DC. (Cactaceae) leaves," Molecules, vol. 14, no. 5, pp. 1713-1724, 2009.

[14] S. Diaz-Moralli, M. Tarrado-Castellarnau, A. Miranda, and M. Cascante, "Targeting cell cycle regulation in cancer therapy," Pharmacology \& Therapeutics, vol. 138, no. 2, pp. 255-271, 2013.

[15] J. A. Call, S. G. Eckhardt, and D. R. Camidge, "Targeted manipulation of apoptosis in cancer treatment," The Lancet Oncology, vol. 9, no. 10, pp. 1002-1011, 2008.

[16] M. A. Dickson and G. K. Schwartz, "Development of cell-cycle inhibitors for cancer therapy," Current Oncology, vol. 16, no. 2, pp. 36-43, 2009.

[17] Y.-L. Cheng, W.-L. Chang, S.-C. Lee et al., "Acetone extract of Angelica sinensis inhibits proliferation of human cancer cells via inducing cell cycle arrest and apoptosis," Life Sciences, vol. 75, no. 13, pp. 1579-1594, 2004.

[18] Z. Yuan, C. Long, T. Junming, L. Qihuan, Z. Youshun, and Z. Chan, "Quercetin-induced apoptosis of HL-60 cells by reducing PI3K/Akt," Molecular Biology Reports, vol. 39, no. 7, pp. 77857793, 2012.

[19] M. A. Masud, Effect of Bioflavonoids Acacetin and Luteolin on HO-1 Human Melanoma Cancer Cells, The Brooklyn Center, Long Island University, 2009.

[20] J. C. Reed and M. Pellecchia, "Apoptosis-based therapies for hematologic malignancies," Blood, vol. 106, no. 2, pp. 408-418, 2005.

[21] X. Qiang, Investigation of programmed cell death mechanisms in Arabidopsis roots during colonization with Piriformospora indica [dissertation], 2011.

[22] E. L. Arriola, A. M. Rodriguez-Lopez, J. A. Hickman, and C. M. Chresta, "Bcl-2 overexpression results in reciprocal downregulation of $\mathrm{Bcl}-\mathrm{X}(\mathrm{L})$ and sensitizes human testicular germ cell 
tumours to chemotherapy-induced apoptosis," Oncogene, vol. 18, no. 7, pp. 1457-1464, 1999.

[23] F. W. Georg, "Cell division and survival," in Molecular Mechanisms of Cancer, pp. 45-191, Springer, 2007. 

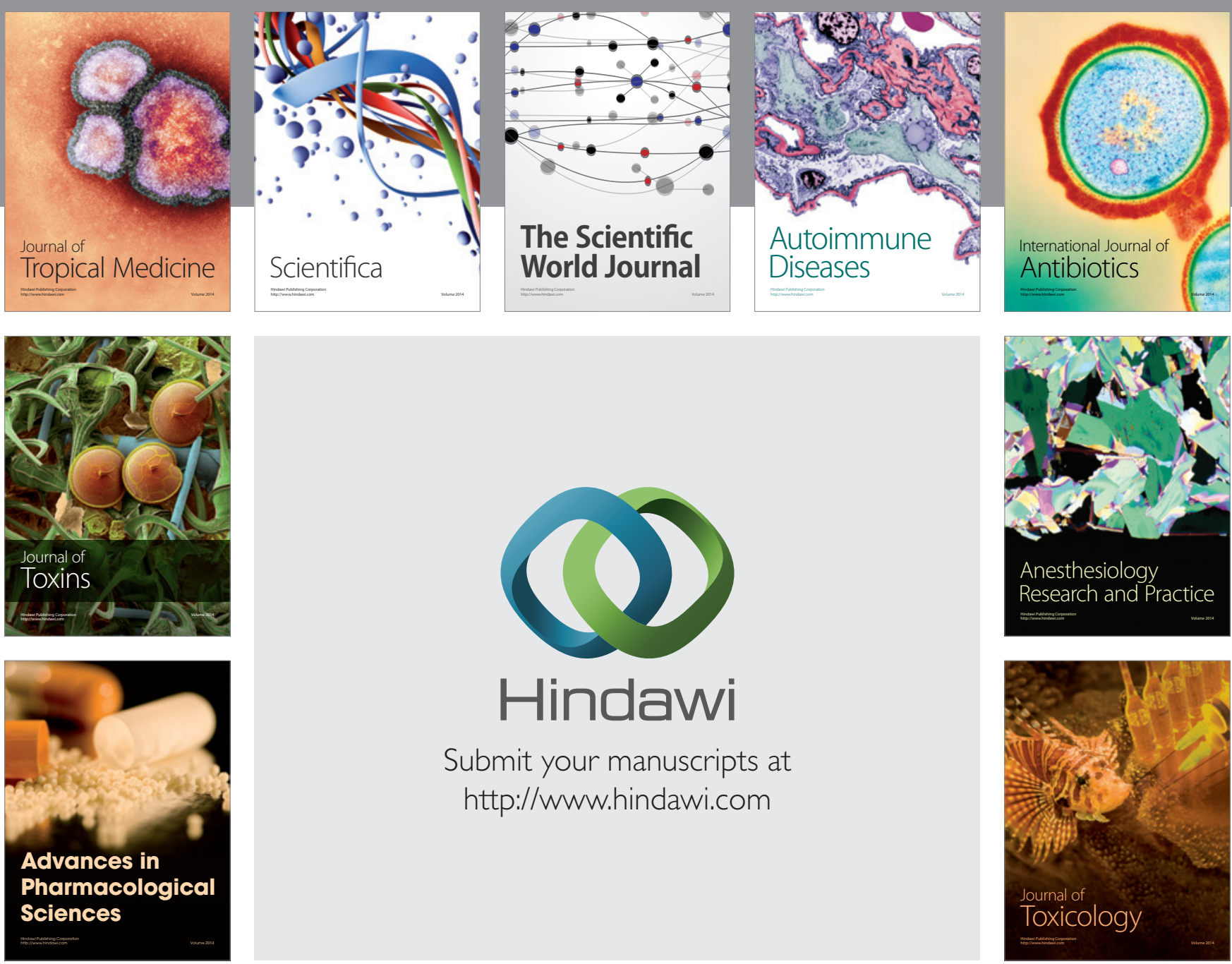

\section{Hindawi}

Submit your manuscripts at

http://www.hindawi.com
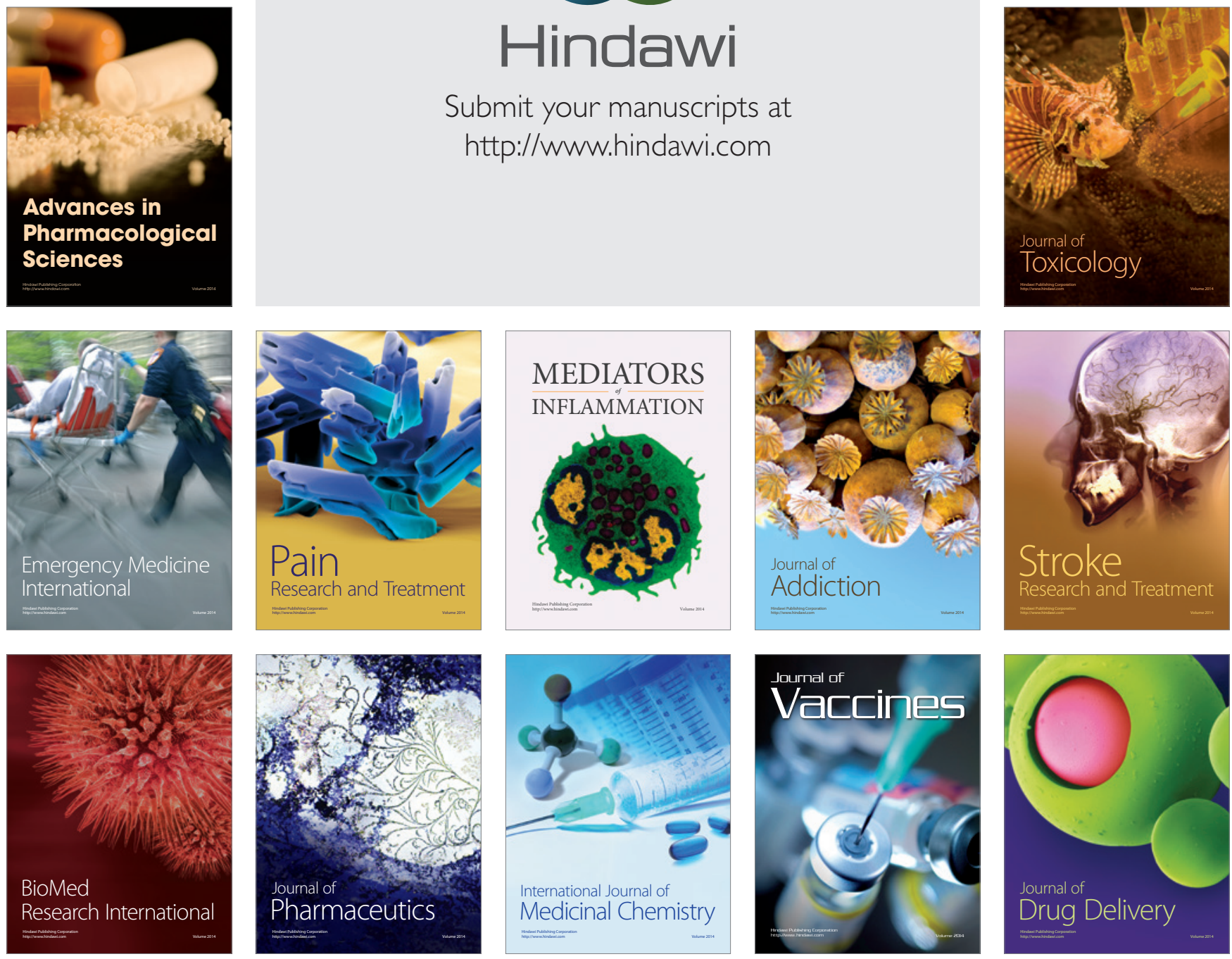